\title{
MULHER E CARNAVAL: MITO E REALIDADE (Análise da atuação feminina nos folguedos de Momo desde o Entrudo até as Escolas de Samba). *
}

\author{
Olga R. de Moraes von Simson **
}

\begin{abstract}
RESUMO: Este estudo remete à ańlise da presença feminina no carnaval do sudeste brasileiro. A perspectiva histórica perpassa as preocupaçũes deste estudo mostrando diferentes opiniōes de observadores. Em 1855 iniciaram-se os limites a atuaçióo da mulher no carnaval e uma abertura maior apenas ocorreu modernamente no Rio de Janeiro.
\end{abstract}

PALAVRAS-CHAVE: Carnaval brasileiro, participação feminina, enfoque histórico-sociológico, cultura popular, história social.

Um exame mais cuidadoso das publicações atuais da grande imprensa brasileira que cobrem os festejos carnavalescos põe imediatamente em relêvo uma visão da mulher como objeto sexual, tanto no que se refere à cobertura dos desfiles de rua quanto às reportagens que focalizam os famosos bailes de Momo. Esse fato vem reforçar a visão do carnaval brasileiro como uma festa em que reinaria um clima de grande permissividade sexual, aspecto esse muito enfatizado também pelas coberturas televisivas veiculadas internacionalmente, as quais tem como principal objetivo atrair turistas para virem participar do carnaval em nosso país.

Pesquisando a memória do carnaval do sudeste brasileiro há mais de quinze anos nos preocupava a discrepância existente entre o papel real exercido pelos elementos femininos nos folguedos de Momo e essa visăo deturpada que os meios de comunicação de massa veiculavam. $\mathbf{O}$ objetivo deste artigo, portanto, é esclarecer, através de uma volta ao passado do carnaval brasileiro, qual o verdadeiro papel exercido pelo elemento feminino na criação, organização, manutenção e evolução dos festejos carnavalescos

* Uma primeira versão deste trabalho foi apresentada no Seminário CARNAVAL CRIAÇÃo E ANÁLISE, promoviclo pelo Núcleo de Pesquisa de Sociologia da Cuitura ciu Instituto de Filosofia e Ciências Sociais da UFRJ e pelo GT Sociologia da Cultura Brasileira C.ERU/ANPOCS, realizado no Rio de Janeiro de 23 a 25 de setembro de 1987.

** Fac. de Educação e Centro de Memória/UNIC:AMP - Centro de Estudos Rurais e Urbanos. 
mostrando que a mulher teve e tem uma participação indispensável na festa de Momo, embora diferenciada segundo as épocas, as camadas sociais e o tipo de folguedo considerado.

Para realizar essa busca da performance feminina na memória carnavalesca, além de uma pesquisa nos jornais editados durante o século passado na cidade de São Paulo e nas principais cidades do Vale do Paraíba, utilizamos os relatos dos viajantes estrangeiros que percorreram nosso país nesse período e se encantaram com os folguedos de Momo, os livros dos cronistas e memorialistas urbanos que registravam aspectos das mascaradas e, para os anos mais recentes, os depoimentos orais de velhos foliões e de dirigentes de entidades carnavalescas que reconstruíram suas histórias de vida sob o enfoque orientador das recordações momísticas. Além dos registros escritos e orais também muito contribuiram para esse resgate da figura feminina nos tempos da folia, os suportes visuais de sua atuação, a qual pode assim ser recuperada e analisada através das gravuras contidas nas obras dos viajantes do século passado e das folos antigas guardadas em velhos álbuns ou esquecidas nos fundos das gavetas e trazidas à luz, a nosso pedido, pelos foliões entrevistados.

\section{A mulher nos folguedos do entrudo}

A primeira manifestação carnavalesca que existiu em nosso país foi o Entrudo, conjunto de folguedos típicos das aldeias da Península Ibérica ligados a práticas sócio-culturais da Europa pré-cristã e para cá transplantados pelos colonizadores lusitanos.

O termo Entrudo englobava uma série de brincadeiras realizadas nos três dias que antecediam o início da Quaresma, além do consumo de um conjunto de comidas típicas desse período festivo. Entre as brincadeiras específicas do Entrudo que aqui se implantaram salientam-se as batalhas aquáticas realizadas com o auxílio de limōes ou laranjas de cheiro, seringas ou bisnagas ou até mesmo baldes ou tinas, quando os ânimos mais se exaltavam; os enfarinhamentos e as peças pregadas em parentes e amigos, além da brincadeira do "Você me conhece?"".

$1 \quad$ O "Você me conhece?" era uma brincacleirn carnavalesca típica de pequenos aglomerados urbanos em que um indivfuluo (vestindo uma fantasia tipo dominó que lhe cobria wodo o corpo e usando míscara, capuz, e luvas) ao se encontrar com um parente ou conhecido começava a relatar, numa vơz de falsete, aspectos intimos da vida do interiocutor para, no final das descriçōes e insinuaçōes soltar a Irase título da brincadeira e afastar-se rapichmente. 
Os brinquedos do Entrudo possuiam um caráter familiar realizando-se geralmente nos sobrados ou da casa para a rua. Era um carnaval que reunia parentes, amigos e conhecidos num folguedo nảo formalizado que, apesar de sua aparente espontaneidade, possuia algumas regras e aspectos que denotavam um nítido contrôle social como na brincadeira do "Você me conhece?".

Ao analisar os relatos dos viajantes estrangeiros e dos memorialistas nacionais sobre o velho brinquedo carnavalesco ficou logo ressaltada a importância da participação feminina, tanto na fase de preparação, como na de realização propriamente dita do folguedo. Mello Morais Filho, um estudioso dos costumes urbanos e do folclore do século passado, assim se referiu à fase de preparação do Entrudo:

"As escravas e as sinhás-moças entregavam-se todo o tempo ao fabrico dos limōes de cheiro que eram expostos à venda em bandejas, cestinhas e pratos, etc., que as famílias colocavam sobre as janelas de suas casas, sobre bancos e cadeiras das salas térreas, ou em tabuleiros à porta dos sobrados, sendo confiada a quitanda a algum moleque ou preta velha que negociava com os compradores ${ }^{2}$."

Quanto a fase de realização dos folguedos percebe-se que, nessa época, os dois sexos participavam igualitariamente da brincadeira, não havendo maiores restrições a atuação feminina. John Mawe assim descreveu o Entrudo na cidade de São Paulo em 1807:

"...homens e mulheres se divertiam então, atirando uns sobre os outros limões e laranjas de cera, cheios de água perfumada ${ }^{3}$."

Se durante todo $o$ ano as mulheres tinham um comportamento recatado, o período do Entrudo representava para elas uma fase de maior liberalidade, quando então podiam assumir atitudes mais ousadas escolhendo os alvos masculinos preferidos para suas laranjinhas perfumadas ou mesmo atraindo comerciantes desavisados para, dentro dos sobrados, lhes aplicar inesperados banhos de água e farinha 4 .

2 Mello Morais Filho - "O Entrudo" in I.OUZADA, Wilson - Antologia de contos de camaval. R.Jan., 1945, 366p., ilust., pag. 129 a 136.

3 MAWE, John - Viagens no interior do brasil. apud Bruno, Ernani da Silva - História e tradiçöes da cidade de são paulo. vol. 1, Ecl., 1954, pag. 385.

4 WALSH, R. - "Notices of Brasil in 1828 and 1829" in LEITÃO, Candido F. de Mello - $O$ Brasil risto pelos ingleses, S. Paulo, 1937, ecl. Nac.- pag. 157 e 158. Mello Morais Filho-Festas e tradiçöe's populares no Brasil. R. Jan. Fauchon \& Cia. Liv. Ed., 478 p., llust., pag. 131. 
A mulheres das camadas mais elevadas cujo comportamento, principalmente no que concerne ao relacionamento com estrangeiros de sexo masculino, era extremamente recatado e reservado, pareciam se sentir liberadas durante os trés dias de loucuras e tomavam a iniciativa dos ataques, escolhendo as vítimas que mais as interessavam. Tal fato parece haver deixado os viajantes estrangeiros um tanto intrigados, pois muitos testemunhos relatam tal tipo de comportamento durante o Entrudo. O primeiro deles aparece no trabalho de Fernand Dénis, o qual entretanto repete informação de R. Walsh descrevendo o Entrudo no Rio de Janeiro na segunda década do século XIX:

"As raparigas brasileiras são naturalmente melancólicas e vivem retiradas, porém, chega o Entrudo e parecem haver mudado de caráter e, por espaço de três dias, esquecem sua gravidade, e natural acanhamento, para do folguedo se darem ${ }^{5}$."

O inglês John Luccock que residiu na Província do Rio Grande do Sul durante algum tempo, nos fornece outro testemunho ao descrever o Entrudo em São Pedro do Sul, no ano de 1809

"Quando de novo se reuniu o nosso grupo, continuei um pouco à frente, com isso escapando de vários disparos isolados; logo porém que alcancei a igreja, fui atacado, de trás de um dos seus cantos, por muitas bolas certeiras, uma das quais quase me rebentou a rédea. Fugi a toda brida, trepei numa duna e dali contemplei a batalha entre meus amigos e as belas amazonas que haviam ficado a espreita, pois que as filhas do Governador tinham se postado ao abrigo de uma basta trouceira a espera da nossa passagem ${ }^{6} . "$

Realmente o tempo do Entrudo parece ter sido um período usado pelas mulheres de família para expressar suas preferências amorosas de maneira mais clara e direta e os dados indicam que provavelmente muitos namoros e casamentos tiveram seu início nessa fase mais liberal do ano. Um pregão das negras baianas que mercavam laranjinhas de cheiro, colhido por Mello de Morais Filho, demonstra esse fato:

5 DÉNIS, Fernando - O Brasil - Salvador, 1955, Liv. Progresso Ed., 1. vol. 413 p. Ilust., pag 253 e seg.

6 LUCCOCK, John - Notas sobre o rio de janeiro e partes meridionais do Brasil. S. Paulo, 1951, Liv. Martins Ed. 2. ecl., 435 p., Ilust. pag. 129. 
"Ahi vai, ahi vai

Laranjinhas de primo

Compre yayá laranjinha

Para entrudá seu amó.

É de yayá, é de yoyô

Quem qué entrudá seu amô?...

Quem entruda seu amô

É sinal de intimidade

Yayá entrude yoyó

Para lhe ter amizade?".

Vê-se então que as mulheres das camadas mais abastadas gozavam o Entrudo de maneira intensa mas tal não acontecia com as negras escravas. Estas trabalhavam duplamente, tanto na preparação dos limões e laranjas de cheiro como posteriormente na venda desses projéteis carnavalescos, forma de auferir uma renda extra para seus senhores ou para si mesmas, caso se tratasse de uma negra liberta 8 .

Além disso a análise dos relatos e das gravuras mostrou que a brincadeira possuia toda uma hierarquia interna que acompanhava as posições da estrutura social vigente e a mulher negra, ocupando o patamar inferior dessa pirâmide, servia de alvo para os banhos e enfarinhamentos produzidos pelos homens negros e não podia reagir a esses ataques; as únicas atitudes que the restavam eram a fuga ou uma defesa relativa através do uso, nesses dias festivos, de suas roupas mais velhas e desbotadas. Jean Baptiste Debret, além de registrar as brincadeiras de Entrudo entre os negros brasileiros em sua magistral gravura "Cena de Carnaval", também as descreveu pormenorizadamente salientando o caráter marginal que tais folguedos possuiam dentro do todo mais amplo dos festejos:

"Para os brasileiros, portanto, o Carnaval se reduz aos três dias gordos, que se iniciam no domingo às cinco da manhã entre alegres manifestações dos negros, já espalhados nas ruas, a fim de providenciarem para o abastecimento em água de seus

$7 \quad$ Mello Morais Filho - op. cit. pag. 129 e 130.

8 Mello Morais Filho - op. cit. pag. 133. BINZER, Ina von - Alegrias e tristezas de uma educadora alemá no Brasil. S. Paulo, 1956, Ed. Anhembi Lida., 137 p., pag. 72. 
senhores, reunidos nos mercados ou em torno dos chafarizes e das vendas. Vê-molos aí, cheios de alegrias e de saúde, mas donos de pouco dinheiro, satisfazerem sua loucura inocente com a água gratuita e o polvilho barato que lhes custa cinco réis. Com água e polvilho, o negro nesse dia, exerce impunemente nas negras que encontra, toda a tirania de suas grosseiras facécias; algumas laranjas de cera roubadas aos senhores constituem um acréscimo de muniçōes de carnaval para o reșto do dia. Ao contrário, a infeliz negra dispenseira, vestida voluntariamente com sua pior roupa, quase sempre azul escura ou preta, volta para casa com o colo inundado e o resto do vestido, marcada com o sinal das mãos do negro que lhe enlambuzou de branco o rosto e os cabelos?."

Conclui-se portanto que para as mulheres negras a fase do Entrudo năo representava um período de alegria ou diversão mas sim um acréscimo de trabalho, alem da preocupação constante com os ataques aquáticos inesperados que, não podendo ser evitados, também não eram passíveis de ser revidados.

\section{O carnaval citadino-burguês $e$ as restriçōes à atuação feminina}

A partir de 1855 uma nova maneira de festejar os dias de Momo foi introduzida em nosso país. Copiando costumes europeus (franceses e italianos) os elementos masculinos das camadas mais abastadas, principalmente estudantes universitários, profissionais liberais e ricos comerciantes fundaram as Sociedades Carnavalescas, associações destinadas a promover grandes cortejos pelas principais ruas e praças dos centros urbanos e bailes luxuosos em hotéis, teatros ou em suas próprias sedes. Esse conjunto de folguedos era denominado Carnaval Veneziano demonstrando sua nítida influência européia e tinha por objetivo promover desfiles nos quais a burguesia saia à rua para divertir o povo.

Tanto nos desfiles processionais (formados por grandes carros alegóricos ou de crítica, animados por bandas e música e aberlos por comissões equestres), como nos animados bailes de máscaras as mulheres de família não podiam tomar parte ativa, ficando restritas à situação de espectadoras da folia 
de Momo. Postadas nas janelas dos grandes sobrados ou nos camarotes dos teatros para "assistir ao carnaval" recebiam flores, doces, confeitos, homenagens e bilhetinhos, mas não podiam participar ativamente da folia; foram convertidas em elementos de embelezamento do cenário, fóco de endeusamento por parte dos membros masculinos das associações, mas não tinham chance de se tornar "partners" ativas nas mascaradas.

O romancista José de Alencar, um dos promotores e grandes entusiastas dessa nova forma, "mais civilizada", de se brincar o carnaval, parece ter recebido reclamações de mocinhas de família, alijadas dos novos folguedos, pois em 1855 prometeu a elas:

"que os diretores do Cassino iriam fazer um baile de máscaras, no qual elas pudessem tomar parte e não ser simples espectadoras como nos teatros ${ }^{10}$."

O levantamento realizado em três jornais paulistanos do século $\mathrm{XIX}^{11}$ confirmou o fato, já sugerido pela bibliografia, de que as grandes folionas do Carnaval Veneziano foram as "mundanas" (prostitutas e artistas de teatro), principalmente as de origem estrangeira que, tendo já algum conhecimento desse tipo de folguedo em seus países de origem, funcionaram como "professoras de folia" introduzindo os paulistanos rústicos, recém enriquecidos pelo "boom cafeeiro", nas novas formas europeizadas de festejar o Deus Momo. Eram elas que, ricamente fantasiadas, adornavam os carros alegóricos nos préstitos carnavalescos e mais tarde dançavam e ceavam com os membros das Sociedades Carnavalescas nos bailes dos teatros ou dos hotéis de luxo.

Nos "puffs", propaganda carnavalesca publicada pelas Sociedades nos principais órgãos de imprensa, às vésperas do carnaval, anunciando e exaltando as atividades a serem desenvolvidas durante o tríduo de Momo e menosprezando e criticando as promoções das sociedades rivais, encontramos as seguintes expressōes nos versos com que a diretoria das associaçōes, carinhosamente convidava as mundanas a virem participar das suas promoçöes carnavalescas:

10 Eneida - História do carnaval carioca. R. Jan. 1958, El. Civ. Bras., 315p. Ilust., pag. 33.

11 Foram pesquisados os jornais Correio Paulistano. A Província de São Paulo, mais tarde O Estado de São Paulo, e $O$ Commercio de Säo Paulo abrangendo o período de 1855 a 1915 , sempre que possível em intervalos regulares de 5 em 5 anos e cobrinclo todo o período carnavalesco que vai de 31 de clezembro au sábacko de Aleluia. 
SIMSON, Olga R. de Moraes von. Mulher e carnaval: mito e realidade.

"Dilectas filhas do amor; "Alai pois borboletas! Nymphas alai! Vinde a nós todas! Filhas do pecado! Correi, voai aos nossos braços... ao prazer sem fim! ${ }^{12}$

Examinando os jornais do século passado editados nas cidades mais importantes do Vale do Parába, recém enriquecidas pelo café na sua marcha rumo a Sāo Paulo, pudemos perceber que a introdução do novo tipo de carnaval acompanhou o florescimento urbano advindo da prosperidade da agricultura cafeeira. Conforme prosperavam as cidades o carnaval ia se modernizando, segundo o modelo da Corte, com a criação das sociedades carnavalescas locais e a realização de luxuosos desfiles processionais e bailes "masqué". Mas, como esses pequenos centros urbanos nāo contavam com uma vida noturna desenvolvida, que fornecesse o necessário corpo regular de "mundanas" de alto nível que seriam as "partners" adequadas para a folia, e ante a total impossibilidade das mulheres de família de participar de tais desfiles, tiveram os organizadores do novo tipo de folguedo que recorrer a rapazes travestidos para suprir os papéis femininos do desfile. Uma descrição do carnaval de Lorena em 1862 demonstra esse fato:

"Dois rapazes vieram de São Paulo, estudantes na certa. E haviam deixado preparadas as surpresas que pretendiam fazer. Para um, cavalo branco com arreio de prata, muito distinto. E para o outro, um burro pacato. Um dos moços, muito claro, barbeou-se, enfarinhou-se e encomendou uma rica roupa branca de bailarina. Trouxe cestos com flores que atirava às moças. Montava muito bem e pôs-se em pé no silhão. Luvas brancas, colo muito bonito, pernas cobertas de meia percorreu a cidade sem que ninguém o identificasse e lá se foi a caminho do $\mathrm{Rio}^{\text {n13 }}$

As mulheres jovens das famílias abastadas, entretanto, não se conformaram por muito tempo com esse papel de deusas passivas da folia e nos primeiros anos do século atual, caleças e tílburis começaram a desfilar levando grupos de mulheres fantasiadas pelas principais ruas, praças e avenidas da cidade, nas tardes dos dias de carnaval. Em São Paulo esse costume era conhecido como "fazer o giro do Triângulo", isto é, percorrer as ruas principais do centro urbano paulistano (ruas Direita, XV de Novembro e São Bento) ricamente fantasiadas, participando da folia sem, no entanto, se misturar com as camadas populares, pois o veículo mais clevado as mantinha

12 Correio Paulistano - 12/02/1893, 06/01/1893 e 28/01/1893 Seçâo Annuncios.

13 QUEIROZ,Carlota Pereira de, - Vida e morte de um capitäo mor. Cons. Est. de Cultura. S. Paullo, 1969, 376p., Ilust., pag. 187 e 188. 
isoladas e em nível superior. Elas contavam ainda com a proteçăo efetiva dos homens da família que desfilavam no banco da frente ou postados nos estribos ${ }^{14}$. Mas, como diz Jorge Americano:

"Durou pouco o corso na cidade. Entre 1910 e 1915 foi transferido para a Avenida Paulista"15.

Na verdade, com a expansăo urbana e a criação de novos bairros a Avenida Paulista, nessa primeira década do século XX já começava a se definir como a artéria elegante da cidade. Ampla, arborizada, permitindo dupla mão de direção, abrigando os ricos palacetes de alguns fazendeiros e principalmente os dos imigrantes recém enriquecidos, foi o palco escolhido pela burguesia para seu desfile carnavalesco, no qual as filhas casadoiras eram postadas, ricamente fantasiadas, sobre as capotas arreadas dos carros, as quais eram recobertas de belas colchas bordadas. A proteção familiar ao rebanho casadoiro aparecia nitidamente pois pais ou irmãos mais velhos, além do chofer, se faziam presentes em todos os automóveis.

Foi a partir de 1911 que os desfiles de carros enfeitados (o corso) passou a ser realizado na Avenida Paulista, sendo que alcançou sua completa organização em 1915, quando essa importante via foi finalmente asfaltada. Nele as mulheres jovens das camadas elevadas estavam presentes como "objeto" a ser visto e admirado mas às quais também já era permitida alguma participação nas batalhas de confeti, lança-perfume e serpentina que caracterizavam o folguedo. Era, entretanto, um brinquedo entre iguais, socialmente falando, pois o público postado nas calçadas só funcionava como espectador do desfile burguês.

Essa manifestação carnavalesca tinha para os membros da burguesia uma dupla função: permitia demonstrar publicamente, tanto para os elementos do seu próprio estrato social, como para o povo em geral, seu poderio económico expresso no carro importado, ricamente enfeitado com flores e ricas colchas bordadas e nas fantasias das mulheres que ocupavam a posição de destaque do desfile. Permitia também, dado o clima de maior liberalidade do folguedo, que rapazes e moças dessa camada social se conhecessem e iniciassem relacionamentos amorosos com a ajuda do lança-perfume, do confeti e da serpentina, embora sob os olhares vigilantes da família.

14 O Estado de São Paulo - 07/02/1910 e 09/02/1910 - pag. 3, Notícias Diversas - Carnaval.

15 AMERICANO, Jorge - São Paulo naquele tempo (1895-1915) S. Paulo, 1957, Ed. Saraiva, 497p. Hust. 
SIMSON, Olga R. de Mornes von. Mulher e carnaval: mito e realidade.

Após as vinte e duas horas, alguns bailes, realizados em salóes elegantes como os do Trianon ou do Teatro Municipal ou em clubes de camada elevada iam contando com a crescente participaçáo feminina, a partir da segunda década deste século. Desde que o folguedo fosse garantidamente realizado entre iguais, socialmente falando, e que as mulheres estivessem acompanhadas por membros masculinos do grupo familiar, sua participação ia sendo gradativamente aceita.

E como se divertiam as mulheres das camadas menos abastadas nesse novo esquema carnavalesco?

De início, o único papel socialmente reconhecido para o povo no carnaval citadino-burguês de influência européia era o de espectador passivo dos desfiles processionais das grandes sociedades. Os dados, colhidos em raras notícias esparsas nas seçôes policiais dos jornais, demonstram que a camada popular, entretanto, não se contentava com esse papel passivo e tentou durante vários anos continuar jogando o velho Entrudo nas zonas periféricas da cidade onde a repressão policial era bem menor ${ }^{16}$. Assim, durante décadas os dois modelos de festejo carnavalesco, o folguedo aldeão arcáico (Entrudo) e o citadino-burguês (Carnaval Veneziano) conviveram nos centros urbanos brasileiros. Nas brincadeiras mais informais e familiares do Entrudo as mulheres continuaram tendo participaçāo, apesar da repressáo policial.

Além disso, mais para o final do século XIX e já no início do XX, começaram a surgir os bailes populares realizados em salóes e teatros, onde os homens pagavam uma pequena taxa, mas a entrada das mulheres era geralmente gratuita. Esse era o grande divertimento das mulheres jovens de vida mais livre da camada popular; para as mulheres "de família" dos estratos mais simples só restava o papel de espectadoras dos desfiles burgueses ou o perseguido brinquedo do Entrudo, no período que antecedeu o aparecimento e o reconhecimento institucional dos folguedos populares.

\section{O surgimento dos folguedos populares e a retomada de uma participação feminina mais ampla no carnaval.}

\section{No Rio de Janeiro}

A cidade do Rio de Janeiro como sede da Corte e posteriormente capital da República funcionou sempre como introdutora de novos hábitos 
carnavalescos para todo o país, tanto para os estratos mais abastados da sociedade como para os folguedos populares. Examinando os primeiros folguedos de caráter popular surgidos no carnaval carioca observamos que tanto no Zé Pereira (folguedo de influência lusitana, inteiramente masculino) como nos cordōes (brinquedo um tanto incontrolável das camadas inferiores) a participação feminina foi nula ou muito restrita. Mas na composição dos ranchos, surgidos no Rio de Janeiro em meados da década de 70 do século passado, as mulheres já estavam presentes em sua estrutua original, como afirma Renato de Almeida:

"os ranchos eram cordões mais civilizados, por assim dizer, pelo menos mais completos, pois já aparecia o elemento feminino ${ }^{17}$."

Realmente, sendo o rancho um produto cultural da população baiana, recém emigrada para o Rio de Janeiro e tendo se originado de uma manifestação profano-religiosa, os Ranchos de Pastorinhas natalinos, incluia desde os seus primeiros desfiles a participação de elementos femininos tanto na organização como na realizaçāo do folguedo. Entre a população emigrante baiana fixada na Côrte após a Guerra do Paraguai e a Revolta de Canudos, criadora desse folguedo, pontilicavam algumas figuras femininas: as famosas tias Siata (ou Assiala), Presciliana, Bebiana e Amélia cujas casas funcionavam como consulados informais da Bahia. Era nas casas dessas senhoras que se reuniam os baianos para tocar e dançar sambas mesclados aos cantos de candomblé.

A imporlância das tias na manutenção das tradições balanas era tão grande que os primeiros ranchos carnavalescos que iam surgindo na cidade da Corte tinham a obrigaçāo, como nos Ranchos de Reis da Bahia, de ir cumprimentá-las em suas casas. Lá eram recebidos com lautas mesas de doces, e então as tias aproveitavam para realizar uma espécie de verificação para se certificarem que os grupos, principalmente os novos que surgiam em grande número, estavam mantendo as tradiçōes baianas do folguedo. Esse costume tomou um caráter semi-oficial pois. após o carnaval, era enviada aos jornais uma espécie de balanço geral. onde se afirmava, como em 1908, que ficara comprovado "o cumprimento das regras que são adotadas nessas diversões oriundas do estado da Bahia ${ }^{18}$." 
Também nas escolas de samba, surgidas na década de 20 , geralmente como resultado da união de blocos carnavalescos existentes nos morros e subúrbios cariocas, a atuação feminina foi fundamental já na sua fase original. Sérgio Cabral, pesquisador do carnaval do Rio de Janeiro, relata que os blocos, gérmens das futuras escolas, surgiram geralmente nas casas das "tias" que costumavam promover, durante $o$ ano, rodas de samba animadas com boa comida e farta bebida. Assim a Estação Primeira da Mangueira se formou da união de dois blocos carnavalescos gestados nas casas de Tia Fé (Benedita de Oliveira) e de Tia Tomásia. A liderança feminina nessa fase de aparecimento do folguedo era tão forte que os blocos eram denominados segundo a tia que os havia criado. Até hoje os velhos mangueirenses se recordam com saudade dos Blocos da Tía Fé e da Tia Tomásia.

Na zona dos subúrbios cariocas surge logo depois a Escola de Samba da Portela, proveniente também da fusão de dois blocos carnavalescos, sendo que um deles, o "Quem fala de nós, come mosca", havia surgido na casa de Tia Ester (Ester Maria da Cruz) - "uma espécie de Tia Siata do subúrbio carioca de Osvaldo Cruz, que promovia rodas de samba em sua casa". ${ }^{19} \mathrm{Na}$ origem da Império Serrano aparece com destaque outra figura feminina, Dona Eulália e foi nessa escola também que, pela primeira vez desfilou uma figura com fantasia de luxo, precursora dos futuros destaques: a sambista Helegária dos Anjos Filho ${ }^{20}$.

Com o desenvolvimento dessas agremições carnavalescas as mulheres foram alargando sua área de atuação passando a ocupar a posição de portabandeira e toda a ala das baianas que, com a bateria constituem o núcleo de base do desfile, na ausência do qual a escola não está apta a desfilar. Depois de 1960 , com o grande incremento dos desfíles cariocas, a participação feminina nas escolas de samba foi se tornando mais diferenciada surgindo as passistas, os destaques femininos, as rainhas de bateria, sendo que nas últimas décadas algumas mulheres conseguiram penetrar até os redutos mais masculinos das agremiações - a ala dos compositores e a bateria - graças à sua comprovada competencia no samba. Dona Ivone Lara na Império Serrano e Leci Brandão e Verinha na Mangueira são os exemplos mais conhecidos de mulheres que hoje integram a ala de compositores, reduto mais tradicional e fechado da criação carnavalesca.

19 CABRAL, Sérgio - "As grandes damas das noites do carnaval" in Vogue-Brasil, $S$. Paulo, fev. 1977 , pag. 76 a 106.

20 CABRAL, Sérgio - op. cit.. 
Mas a luta das mulheres para ocupar todas as posições possíveis no desfile carnavalesco não foi feita sem dificuldades. Dona Ivone Lara, "autora de um samba tido como hino do Império Serrano", sempre sentiu, assim como Leci Brandão, a oposição de seus colegas compositores que, numa atitude machista procuravam dificultar a atuação das sambistas. Para superar essas dificuldades e impor seu talento de compositora, as duas sambistas dinamizaram a carreira de sambista profissional participando de shows, fazendo televisão e gravando discos. Apesar do sucesso, reconhecido pela sociedade mais ampla, Dona Ivone Lara prefere hoje desfilar na ala das baianas da Império Serrano porque lá ela se sente muito melhor e, segundo ela, os colegas da ala dos compositores, depois que seu primo Mestre Fuleiro deixou o cargo de Diretor de Harmonia:

"começaram a fazer política contra mim. Não na minha presença, mas o fato é que não gostavam que eu ficasse lá. Achavam que mulher não deve tomar parte na ala dos compositores ${ }^{21}$."

A liderança no mundo do samba não se constroe, entretanto, apenas através do desfile carnavalesco. Há outros aspectos da vida das comunidades sambistas que concorrem para a formação de seus líderes. Há a tradição e a competência no samba que são fundamentais mas a "doação" de serviço desinteressado e a força política também constroem lideranças, independentemente do sexo de seus detentores. Assim, algumas mulheres aparecem como verdadeiras "matriarcas" no espaço do samba possuindo poder para opinar nas decisões importantes relativas à vida das agremiações e definir, até politicamente, a escolha da diretoria das entidades carnavalescas.

No morro da Mangueira, por exemplo, duas lideranças femininas dividem seus habitantes: Dona Neuma e Dona Zica, carinhosamente chamadas de tias por todos da Estação Primeira. São elas que cuidam dos problemas mais prementes dos membros da escola (uma criança prestes a nascer, uma doença inesperada ou um acidente que exige rápido socorro), lutam também zelosamente tanto pela manutenção das tradiçôes de sua escola querida, como pela melhoria das condiçôes de vida dos habitantes da região.

A existência dessas matriarcas do samba não se restringe à Estação Primeira da Mangueira: há a tia Dóca da Portela, em cujo quintal "em Osvaldo Cruz ressurgiu em 1978 o pagode, que hoje é uma verdadeira mania

21 CABRAL, Sérgio - op. cit.. 
nacional" 22, há também tia Zezé do Salgueiro que habita uma meia-água no pico do morro e "é respeitada com a mesma reverência pelas famílias e pelos malandros" ${ }^{23}$; além de outras anônimas que, mesmo sem serem conhecidas, vão mantendo, durante todo o ano a coesão entre os sambistas, valorizando as raízes dessa manifestação carnavalesca, como faziam as velhas tias baianas com os ranchos pastorís do início do século.

\section{$\underline{\text { Em São Paulo }}$}

O primeiro folguedo carnavalesco de caráter popular que surgiu no carnaval paulistano, nas últimas décadas do século passado, apesar de haver se originado das antigas procissões coloniais, nâo apresentava nenhuma mulher na sua estrutura ${ }^{24}$. Era o Caiapó, dança dramática, apresentada pelos negros paulistanos ao som de tambores chocalhos. Através do folguedo eles denunciavam a opressão dos brancos em relação às demais etnias constituintes da população paulistana, representando ao longo da dança a morte e ressurreição do pequeno cacique caiapó ${ }^{25}$.

No primeiro cordão surgido na Barra Funda em 1914, a atuação das mulheres se limitou, a princípio, a ajudar a organização e montagem do folguedo, nâo participando do desfile; havia um certo temor, por parte dos dirigentes, de uma possível repressão policial a um folguedo organizado por negros, coletividade que tinha estado alijada, por muitos anos, dos festejos públicos de Momo na cidade.

O Grupo Carnavalesco da Barra Funda, popularmente denominado Camisa Verde, só passou a incluir mulheres no desfile, bem mais tarde, em 1921; dessa data em diante, a participação feminina foi cada vez mais ampla. Elas continuavam auxiliando na organização do folguedo, incumbindo-se também do ensaio do setor mirim, o Infantil da Barra Funda. No desfile as mulheres constituiam o grupo das "amadoras" que se apresentava em filas

Idem.

24 As mulheres das camachs populares saiam nas antigas procissões na ala ou grupo das quitancleiras, vestidas com roupas semelhantes as das baianas e portando os tabuleiros caracteristicos de sua profissño. Para maiores daclos consultar: Muniz Jr. - Do batuque à escola de samba. (Subsídios para a história do samba) S. Paulo, Ed. Símbolo, 1976, 207 p., Ilust.

Para maiores dados sobre as Cainzós consultar: von SIMSON, Olga R. de Moraes - A Burguesia se diverte no neinado de momo (Sessenta anus de evoluçåo to carnaval paulistano) 1850/1915 - Dissertaçîo de Mestrado - FFLC:LI/USP, 1984 (mimeo). 
paralelas, de duas a duas, obedecendo às ordens do ensaiador ou mestre de cerimônias e realizando elaboradas evoluções que enriqueciam as apresentações do cordão.

Dirigentes e organizadores dos desfiles percebiam a importância da participação do elemento feminino nos cortejos de Momo e valorizavam o enriquecimento que ele trouxe aos desfiles; uma das marchas-sambadas, especialmente composta para as apresentações do Camisa Verde, na década de 20, que constava do velho caderno de Dona Antonia, figura importante do cordão, assim se referia às mulheres da agremiação:

"Tem pretinhas, mulatinhas, que tomam parte no festival, temos cabrochas da pontinha, para gozar o carnaval!" 26

No Vai-Vai, surgido por volta de 1928 ou 30 , as mulheres também não sairam no primeiro ano, mas no segundo desfile já estavam incorporadas à agremiação $^{27}$. Apesar de não trazer elementos femininos no seu primeiro cortejo, o Vai-Vai contou com a participação de algumas crianças, inclusive uma que se tornaria uma legenda no carnaval paulistano: Dona Sinhá - a Dama do Samba, que mais tarde se tornaria a famosa matriarca do Camisa Verde. Ela assim recordou a sua estréia nos folguedos carnavalescos, aos doze anos de idade:

"Ah,... primeiro ano que saiu (o Vai-Vai) minha mãe já deixou e eu saí de baliza. Porque antigamente tinha esses negócio de baliza. Era bacana, sabe... A baliza é que vinha abrindo... gente em pessoa. Saí eu, saiu um rapaz chamado Genésio, saiu... Tinha uma porção, não me lembro o nome. De mulher era só eu. Eu saí de homem, a gente vinha com aquele pauzinho, jogando o pau no meio da rua, com aquela capa, jogando a capa e abrindo o caminho para a "escola" vim vindo atrás... Era uma função muito bacana, porque vinha uns dez baliza, tudo abrindo assim a "escola", jogando pau prá cima, virando cambota, plantando bananeira, cada um fazia o que queria ${ }^{28}$." vo do carnaval brasileiro do CERU., pag. 47.

27 Segundo depoimento de Seu Livinho (MIS/CERU), pag. 10, (Seu Livinho foi fundador do VaiVai e apitador do cordâo na sua primeira fase.) Arquivo do carnaval brasileiro do CERU. 
O talento, a competência e o entusiasmo parecem ter orientado a definição de papéis dentro do desfile carnavalesco compensando uma certa atitude machista dos dirigentes que, a princípio, dificultou a integração de mulheres ao folguedo. Percebe-se esse fato pela descrição da maneira como Dona Sinhá foi selecionada para ser um dos balizas da Vai-Vai:

"Quando tinha ensaio, a gente ia no ensaio... aí como eles viram que eu pulava muito, isso e aquilo: '-Ah, cê não qué saí de baliza? Eu pedi consentimento prá minha mãe. Ela disse: '- Pode saí.' Aí eu fui tratá da minha roupa e tudo bem ${ }^{29}$."

E pelo depoimento de Pé-Rachado ao lembrar os primeiros puxadores de samba surgidos no carnaval paulistano:

"...Porque no tempo que não havia puxador de samba ele (o Tino) já era puxador do Vai-Vai.... apesar de fazê as música ele puxava na Avenida também. Como cordão... (nenhum), ninguém tinha (puxador de samba). Aliás minto. $\underline{\mathrm{O} C a m p o s}$ Elísios tinha Dona Cecília! E o Vai-Vai tinha o Tino....

O cordão surgido entre a mocidade da Saracura ${ }^{31}$ foi tomando, com o passar dos anos, um caráter quase familiar, agregando mulheres e crianças, cada vez em maior número. Na década de 40 , as mulheres do Vai-Vai conquistaram definitivamente uma posição que até então havia sido privilégio de homens e crianças: a de baliza ${ }^{32}$. Algumas mulheres baliza ficaram famosas por sua leveza e flexibilidade acrobática, como também por sua coragem, ao assumir inteiramente todos os riscos inerentes a essa função:

28 Depoimento de Da. Sinhá (Vai-Vai/Camisa Verde) MIS/CERU., png. 3, Arquivo do carnaval brasileiro do CERU.

29 Idem, pag. 2.

30 Depoimento de Pe-Rachado (Vai-Vai e Barroca Zona Sul) MIS/CERU, pag. 39 e 40, Arquivo do carnaval brasileiro CERU. Grifo nosso.

31 Saracura, setor do Bexiga (Bela Vista) mais próximo do vale do antigo Riacho Saracura, habitado na época em sua maioria por elementos negros. Posteriormente o riacho foi canalizarlo dando lugar a Av. Nove de Julho.

32 O baliza foi um elemento típico dos cordões paulistanos. Introduzido no desfile por Dionfsio Barbosa que se inspirou nas apresentaçōes do Batalhão 53 que êle havia assistido no Rio de Janeiro. Esse elemento possuia dupla função no desfile carnavalesco: - abrir espaço entre o público para que o cordấo pudesse desfilar pois não havia, por essa época uma infra-estrutura organizada para as apresentaçóes carnavalescas. O baliza fazendo acrobacias, abrindo sua ampla capa de seda e jogando para o alto e para os lados seu bastâo de madeira, cumpria essa tarefa. além disso, no caso de disputas entre cordões rivais, cabia também a êle defender o estandarte da agremiação. 
Ondina, Risoleta Alzira são até hoje lembradas quando se fala, com saudade, dos velhos tempos do "Orgulho da Saracura" 33 .

O elemento feminino vai ocupando sucessivamente, ao longo dos anos de crescimento do Vai-Vai, as posições de porta-estandarte, primeiro destaque, rainha, damas, princesinhas, além de desfilar também anonimamente entre as pastoras. Elas demonstraram sempre muita garra, ignorando empecilhos e dificuldades que certas fases da vida feminina, como a gravidez ou o período de amamentação, poderiam apresentar e apesar dos entraves naturais, não deixavam de participar dos desfiles de sua agremiação querida.

Alguns depoimentos prestados por veteranas folionas do Vai-Vai atestam vivamente com que prazer, elas participavam das folias carnavalescas. Disse Odete:

"Que desgraça! Eu num... digo prá você que cordão era uma coisa maravilhosa! A gente saía... Aquele... quando batia o surdo lá embaixo, aquele (som).... estremecia a barriga da gente. Sentia aquele ritmo, aquela coisa, que nem que a gente quizesse, a gente ficava doida, abandonava tudo! Nossa Senhora, eu saía "dando mamá". A minha sogra, mãe dêle (de Genésio, também presente à entrevista) bebia bem pinga e vinha atrás de mim: '-Toma seu filho!' Com aquela armação (da fantasia) como é que eu ia fazê? Pedia pruns "bebum" também que táva acompanhando a escola, o cordão:

'-Pega aí o meu filho'."

"Na rua Direita, uma vez, minha sogra me deu, num sei se foi esse, sei que era um dos... dos premêro filho, bem bêbeda: '-Toma seu filho, cê tá aí dansando e eu aqui carregando ele!' Na rua Direita, eu num sabia... (o quê fazer) e bem na hora do desfile principal! - O que eu passei com a mãe dele não foi brincadeira. - Então, sempre tem um: '-Não, dá aqui, dá aqui...' E eu era das principár, né? Num podia... Então pegava (a criança) até eu desfilá e depois (eu) parava prá dá de mamá. O quê que é isso? Quanta loucura, né?... E, era lindo, era lindo! Então depois mamava, a criança dormia, pegavam lá, levavam e eu continuava ${ }^{34}$."

Dona Iracema, outra veterana do Vai-Vai, relembrando seus tempos de mãe-sambista, perguntou ao filho, também presente à entrevista:

"...cê lembra, quando cê era pequeno eu levava você? Eu tinha meus filho, eu levava tudo no cordão. Eu, "pesada" carregava tảmbém o estandarte, também fui

33 Depoimento de Odete e Genésio, pag. 4 e 16 e depoimento de Pé-Racahado, pag. 6. Arquivo do carnaval brasileiro do CERU.

34 Depoimento de Odete, pag. 26. Arquivo do carnaval brasileiro CERU. 
SIMSON, Olga R. de Moraes von. Mulher e carnaval: mito e realidade.

porta-estandarte e saía... depois saía na Comissão (de Frente), a gente sempre trocava, quando não podia. Tinha que vê, era uma maravilha o cordẫo do Vai-Vai ${ }^{35}$."

As mulheres do Bexiga foram participantes entusiastas de todas as fases do processo carnavalesco, inclusive dos entreveros que se davam por ocasião da divulgação dos resultados dos concursos. Odete assim recordou os apuros por que passou ao tomar parte, nas décadas de 50 e 60, das refregas que aconteciam em frente às emissoras de rádio, quando eram anunciados os campeões do ano:

"Eh, mas quando falava: 'Vai-Vai em primeiro!', o Camisa misturava com o VaiVai e a gente ou "de barriga", ou de dieta, ou com criança. As criança agarrando, as criança entrando embaixo da saia prá sumir do meio da confusão, com tudo isso, a gente tinha aquele outro... era outro entusiasmo! ${ }^{36_{\text {"n }}}$.

A participação feminina se estendeu finalmente a todas as atividades de Momo, não deixando nenhum aspecto de lado. Até uma atividade mais arriscada e agressiva, como o Bloco do Esfarrapado ${ }^{37}$, contava com grande participação do sexo frágil. Pé-Rachado, ao explicar esse antigo costume da turma do Vai-Vai, salientou a participação de mulheres de todas as idades no mesmo!

"...ia a mulherada tambem. Ia menina, ia alguma velha que gostava mesmo de samba, ia também. Não tinha problema ${ }^{38}$."

Dona Sinhá também confirmou a participação feminina no Bloco do Esfarrapado, lembrando, com saudade, seus tempos de foliona do Vai-Vai:

Depoimento de Dona Iracema, Arquivo do carnaval brasileiro do CERU.

Depoimento de Dona Odete, p. 8. Arquivo do camaval brasileiro do CERU.

37 O Bloco de Sujo ou Desfile dos Esfarrapados parece ter safdo a princípio, nas segundas-feiras quando esse dia ainda era considerado dia normal de trabalho, o que impedia um desfile regular da agremiaçấo. Mais tarde, o Desfile dos Esfarrapados foi transferido para o súbndo, sendo abolido definitivamente na década de 50, para evitar uma possivel danificação dos instrumentos da bateria, ainda antes dos desfiles principais. $O$ costume ressurgiu há alguns anos, mas como uma atividacle ligada a recriaçăo das tradiçỏes do Bairro do Bexiga, não mais vinculado ao Vai-Vai. Depoimento de Pé-Rachacho CERU/MIS. P. 22, Arquivo do carnaval brasileiro do CERU. 
"Eu sei que até esperando nenê eu saía também. Com uma baita barrigona, eu saía. Tinha Bloco de Sujo que saía na segunda... eu vestia a roupa do avêsso, a saiona de baixo por avesso e saía no Bloco de Sujo ${ }^{39}$."

Parece que por não terem podido participar ativamente, na sua juventude dos folguedos de Momo, tendo que funcionar durante muitos anos como público espectador da folia, a maioria das mães dos sambistas foram introdutoras entusiastas de seus filhos no mundo do carnaval. São frequentes, nos relatos colhidos, mençóes ao fato de que elas levavam as crianças para assistir aos desfiles, confeccionavam fantasias para seus filhos ou se já estivessem engajadas em uma agremiação, faziam questão de que seus filhos participassem, junto com elas, das brincadeiras de Momo. Dona Sinhá, exemplo de sambista surgida nessa fase heróica, relembrou aspectos de sua infancia ligados ao carnaval que bem esclarecem o importante papel de incentivadora exercido pelas mulheres:

"...As mães, tudo procurava fantasiá seus filho, quando era pequeno. Assim eu mesmo, minha mãe fazia fantasia de Pierrô. Ia tudo prá avenida e ficava tudo sentado na calçada prá assisti passá aqueles carros. Era lança-perfume, confete, serpentina. Eles jogavam, era muito bacana... A turma, todo mundo, era geral, ia prá avenida Paulista. Prá assistí o carnaval da Paulis$\mathrm{ta}^{40} . "$

Ou lembrando especificamente a figura de sua mãe:

"Minha mãe nunca saiu (nos cordóes), mas ela apreciava muito, ela gostava muito! Sairam tudo os meus irmãos no Vai-Vai... minha família saía, meus irmãos, minhas irmãs sairam... $41_{\text {" }}$

Dona Olímpia, veterana foliona do Bexiga, falando de sua primeira experiência carnavalesca, também testemunhou a importância da figura materna:

39 Depoimento de Dona Sinha C.ERU/MIS, p. 10. Arquivo do carnaval brasileiro do CERU.

40 Idem, p. 25.

41 Idem, p. 25. 
"O primeiro cordão que eu fui veterana também, foi o Campos Elíseos, mas eu era menina, eu tinha uns doze anos... Eu ia, minha mãe, minha falecida mãe levava ${ }^{42}$."

Seu Zézinho do Morro da Casa Verde, outro baluarte do samba paulistano, fundador de várias agremiações e participante ativo de todas as fases do carnaval negro da cidade, ao relatar a maneira como se integrou, aos oito anos de idade, no Cordão Camisa Verde, também salientou a importância materna nesse processo:

"...mas eu conheci o Barra Funda em 1918, a minha mãe me levou pruma destas festas que tinha em São Bom Jesus de Pirapora... a mãe me levou prá lá. Foi lá que eu fiquei conhecendo o Barra Funda... Então quer dizer que, em 18 eu desfilei lá com eles, lá em Pirapora... com o Grupo Barra Funda. Quando foi em 20, eu já comecei a desfilar aqui em São Paulo. Não tinha bem a noção das coisa ${ }^{43}$."

Esse papel feminino, atuando ora junto aos membros da família, ora junto à agremiação carnavalesca, não só incentivando mas também garantindo a criação e manutenção dos folguedos foi constatado em relação a épocas diversas do desenvolvimento dos folguedos negros na cidade, em relação a diferentes tipos de entidades carnavalescas e às diversas fases da vida das agremiações. Nas escolas de samba, sucessoras dos cordões paulistanos como atrações máximas do desfile de Momo, a atuação feminina vem se mostrando também fundamental nas diversas etapas vivenciadas por esse folguedo na cidade de Sáo Paulo.

Mas o papel mais fundamental exercido pelas mulheres, ao longo da vida dos cordóes, foi aquele que possibilitou a própria permanência desse folguedo enquanto principal manifestação negra no carnaval paulistano. Nos anos que se seguiram ao término da Segunda Guerra Mundial, a cidade de São Paulo passou por um rápido processo de transformação, quanto ao tipo de população que ocupava cada um dos seus diferentes bairros. Durante todo o Conflito Muridial, devido a falta e aos altos preços dos materiais interromperam-se as construçöes de novas moradias, principalmente aquelas destinadas ao aluguel por parte de elementos das classes mais pobres, havendo então, ao

42 Depoimento de Dona Olímpia, p. 9. Arquivo do carnaval brasileiro do CERU.

43 Depoimento de Seu Zézinho do Morro da Casa Verde C.ERU/MIS - p. 3. Arquivo do carnaval brasileiro do CERU. 
final da década de 40 e início da de 50, uma grande escassez de habitações. Tal fato provocou uma rápida valorização dos aluguéis obrigando as famílias mais pobres a deixarem os bairros centrais, buscando a periferia onde, através da construção de pequenas moradias em lotes mais acessíveis, ou alugando casas mais baratas, foram se reassentando em zonas mais distantes do centro da cidade. Nabil Bonduki que estudou o fenômeno explica:

"O problema dos despejos se constituiu, no período pós-guerra e no período populista, no mais importante e angustiante problema habitacional surgido nos bairros tradicionais e consolidados de São Paulo. O significado real desta questão é mais amplo do que a primeira vista poderia parecer: representa o processo concreto de expulsão da população de baixa renda das moradias de aluguel produzidas comercialmente por empreendedores privados em áreas urbanas relativamente bem equipadas e situadas próximas aos locais de emprego. É bastante difícil estimar o total de famílias despejadas durante o período mais agudo da crise de habitação, ou seja, entre 1945 e 1948 . Em 1945 foram assinadas pelos juízes 2.614 ações de despejo, número que subiu a 5.121 em 1946 e que atingiu, somente em janeiro de 1947, 491 casos." ....."Assim, tomando somente os dados oficiais relativos aos anos de 1945 e 1946 e considerando num cálculo otimista, que cada ação de despejo atingia uma média de duas famílias, teríamos para estes dois anos mais de 15.000 famílias despejadas, ou seja, aproximadamente 75.000 pessoas. Este total corresponderia a mais de $4 \%$ da população de Săo Paulo destes anos. Tendo em vista que a crise de habitação se estendeu pelo menos até 1948 e que o número real de despejos ultrapassa a estatística jurídica, pode-se afirmar que os despejos atingiram na época entre 10 e $15 \%$ dos paulistanos, o que nos dá a idéia da extensão do fenômeno ${ }^{44}$."

Viver próximo ao centro urbano havia se tornado, para quem não era proprietário do seu imóvel, praticamente impossível, o que afastou as classes menos privilegiadas até mesmo dos bairros negros os quais, por outro lado, através de algumas obras de urbanização, como por exemplo a construção do Túnel Nove de Julho, estavam se transformando em locais de moradia mais valorizados.

Dessa forma, os cordões surgidos no início do século em zonas urbanas centrais desvalorizadas e habitadas por muitos negros, se viram, num espaço de tempo relativamente curto, sem o suporte dos grupos de vizinhança que 
lhes haviam dado origem. Nesse rápido processo de reordenação populacional vivido pela cidade de São Paulo, muitas entidades carnavalescas acabaram desaparecendo, mas algumas, mais antigas e melhor estruturadas, foram capazes de sobreviver. Os elementos femininos dessas entidades tiveram um papel fundamental nesse processo de sobrevivência.

As lideranças femininas desses cordōes forçadas pelas circunstâncias a habitar bairros afastados como: Jabaquara, Bosque da Saúde, Vila Brasilândia, Taboão, Ferreira, Vila Maria, Vila Guarani, não se conformando em ficar alijadas dos festejos carnavalescos, criaram um novo esquema de organização e realizaçăo dos ensaios para o desfile, transformando suas residências numa espécie de pequenas filiais da sede da agremiação.

Através de contatos constantes com a diretoria do cordão e de visitas regulares à sede, em busca dos modelos para as fantasias, da letra do sambaenrêdo e mesmo de alguma ajuda, ou financeira, ou em tecidos, as mulheres, geralmente as costureiras, passaram a organizar alas inteiras do cordão nos novos bairros onde haviam passado a residir. Elas confeccionavam os disfarces e realizavam, em suas casas, os ensaios preparatórios para o grande ensaio final, este sim realizado na sede central da agremiação, às vésperas do Carnaval.

As diretorias dos cordóes percebendo a grande importância de tais "filiais" periféricas para a manutenção do folguedo, rapidamente se adaptaram para melhorar o funcionamento do novo esquema criado pelas costurejras. Pé-Rachado, que dirigiu o Vai-Vai por mais de vinte anos e vivenciou justamente essa fase de transição, relembrou, em seu depoimento, que eram tantas as visitas que precisava fazer à periferia, levando modelos de fantasias, tecidos, instrumentos musicais e mesmo alguns batuqueiros para animar os ensaios em bairros afastados, que ele resolveu comprar uma perua para realizar o trabalho de coordenação dos desfiles. Frizou também a importância fundamental das lideranças femininas como incentivadoras e organizadoras de novas alas do cordão, que se disseminavam agora pelos bairros periféricos da cidade, onde quer que houvesse um contingente de populaçảo negra e uma ex-residente do Bexiga.

Vários relatos descrevem como essa rêde de elementos femininos foi aglutinando os membros dispersos da escola em torno de suas oficinas de costura, as quais ao funcionarem como elos de ligação com a sede da agremiação, permitiram a permanência das entidades tradicionais no desfile carnavalesco, demonstrando uma resistencia cultural capaz de superar os entraves criados pela vida num centro urbano em rápida expansão.

A partir dessa reorganização espacial do funcionamento dos cordões e das escolas de samba, tornou-se possível uma aceleração de seu crescimento, 
tanto numérico quanto qualitativo, pois como repercussão dos sucessos obtidos nos desfiles, foi havendo a incorporação de novos membros provenientes de vários estratos sociais e com diversa formação profissional que residindo nos bairros mais periféricos se integravam às escolas, via novas filiais criadas pelas costureiras.

Depois da oficialização dos festejos carnavalescos paulistanos ocorrida em 1968, sob a égide do Prefeito Faria Lima, observamos o aparecimento de um outro tipo de escola de samba, não mais surgido a partir de um antigo cordão ou reunindo habitantes de uma zona da cidade com predominância de população negra. Estas são escolas que já surgiram com o objetivo claro de competir no desfile oficial, num esquema de carnaval-espetáculo, contando muitas vezes com o patrocínio de empresas ou associações comerciais e geralmente sob uma direção branca. Nos anos mais recentes, observamos o surgimento de departamentos femininos, tanto nas escolas tradicionais como nas mais novas, mas já com certa envergadura, acompanhando uma visão mais empresarial que propunha que as escolas devem ser capazes de gerar recursos com meios próprios, ao longo do ano, para subvencionar um bom desfile carnavalesco. Nesse aspecto as escolas repetem uma tendência geral da sociedade, a exemplo do que vem acontecendo em outras associações, como partidos políticos e sindicatos, que passaram mais recentemente a reconhecer a importância da atuação feminina no âmago dessas organizações $^{45}$.

Mas, esse novo departamento que passa a integrar a estrutura das escolas de samba, apesar de aparentemente valorizar seu contingente feminino, reservando-lhe um espaço próprio, tem se constituido na verdade num instrumento de reafirmação do papel tradicional atribuido à mulher pela sociedade mais ampla. Segundo a visão da diretoria das escolas, o Departamento Feminino deve se encarregar dos setores costumeiramente ocupados pelas mulheres: as alas das pastoras e das baianas, além de ficar responsável pela ala mirim, quando ela existe. Deve também coordenar o trabalho das costureiras, cuidando para que sigam o figurinos fornecidos pela sede central e cumpram os prazos estipulados pela direção.

É entretanto, nas promoções de meio de ano que essa visão tradicional do papel da mulher fica ainda mais reforçada, pois nesses eventos cabe ao Departamento Feminino cuidar principalmente da cozinha (papel específico da mulher na sociedade brasileira, principalmente da mulher negra) e algu- 
SIMSON, Olga R. de Moraes von. Mulher e carnaval: mito e realidade.

mas vezes se ocupar também da decoração da quadra para o maior sucesso das festividades.

Percebe-se então que os novos departamentos das escolas de samba não vem se caracterizando como um espaço de resistência feminina, onde as mulheres possam batalhar, dentro de sua própria agremiação, seja para uma maior participação feminina em todos os setores da entidade e na sociedade mais ampla, seja por melhorias internas que viessem beneficiar a elas e aos membros mais jovens da associação. Esses departamentos são na verdade, uma espécie de coordenação, encarregada de receber tarefas da diretoria e repassá-las para seus membros, (cuidando para que sejam bem efetuadas), tarefas essas relacionadas aos papéis tradicionalmente exercidos pela mulher na sociedade brasileira.

O papel fundamental da mulher na criação, evolução e manutençăo dos folguedos carnavalescos reconstituido ao longo desta análise, não vem sendo reconhecido pela diretoria das agremiações carnavalescas e talvez nem seja conscientemente percebido pelas próprias mulheres sambistas. Até hoje os elementos femininos não são vistos dentro da escola de samba como companheiras na tarefa de bem realizar o folguedo, com iguais direitos e deveres pois, como vimos, alguns setores das agremiações ainda lhes são vedados e quando se cria uma secção específica feminina, esta não apresenta um caráter inovador da participação das mulheres na associaçāo, apenas vem reforçar 0 papel tradicional e socialmente aceito para o segundo sexo.

Esta análise da memória do carnaval, enfocando através de dados empíricos a atuação das mulheres nas folias de Momo, mostrou que enquanto os folguedos se davam sob a égide do grupo familiar (a fase do Entrudo) a participação feminina não encontrava maiores obstáculos, talvez refletindo papéis femininos relevantes, ao nível da organização familiar, exercidos durante todo $o$ ano.

Com a transformação dos folguedos, na segunda metade do século passado, e a introdução do Carnaval Veneziano que era realizado em espaços públicos (ruas, praças, salões e teatros), a mulher burguesa teve sua atuação carnavalesca tolhida, tornando-se apenas espectadora dos desfiles e dos bailes. Mas as reclamações femininas forçavam uma ampliação dos seus espaços no ambito da folia com a introdução do corso e dos bailes em clubes fechados. Isto lhes foi concedido, desde que houvesse certas garantias de que as brincadeiras carnavalescas se dariam entre iguais, socialmente falando. Quando, entretanto, o aumento do número de veículos automotores, a partir do final da década de 40 neste século, provocou uma "democratização" do corso, as famílias mais abastadas se retiraram do folguedo, passando a viajar para estancias minerais ou climáticas, onde o pequeno tamanho dos núcleos 
urbanos permitia que o carnaval ainda pudesse ser festejado entre iguais. Tal fato parece ter sido um dos fatores determinantes do desaparecimento desse tipo de brincadeira carnavalesca.

Quanto aos folguedos populares, observou-se uma participação feminina efetiva desde seu surgimento, muito provavelmente por haverem se originado como brincadeiras familiares. Apesar dessa atuação relevante das mulheres, há ainda nas escolas de samba atuais, redutos que lhe são barrados: os cargos de direção, o setor de criação carnavalesca (a ala dos compositores) e aquele que é responsável pela manutenção da coesão e integridade da agremiação no desfile (a bateria). Quando uma mulher demonstra talento excepcional para alguma dessas atividades, observa-se até sua aparente aceitação, mas as pressões sociais, principalmente masculinas, vivenciadas no exercício da nova função são tão fortes, que geralmente ela não consegue manter o posto conquistado.

Com o crescimento e evolução das escolas de samba, transformandose gradativamente em verdadeiras empresas carnavalescas, as mulheres vem sofrendo uma setorização da sua participação a qual vai sendo restrita aos papéis femininos bem aceitos pela sociedade mais ampla. São as funções ligadas à tradição, à família, e ao lar que lhes são reservadas, mostrando que em todos os níveis sociais o espaço feminino, para ser institucionalizado, deve assumir seus contornos tradicionais, não importando a participação efetiva das mulheres na fase heróica de consolidaçâo e afirmação das agremiações.

Essas restrições à participação feminina em cargos de direção das entidades carnavalescas vem sendo mascaradas pela intensa valorização das mulheres jovens e bonitas como elemento decorativo do desfile carnavalesco. Cada vez mais elas aparecem ricamente despidas e elevadas à posição de grande destaque visual no espetáculo carnavalesco, reforçando assim mais um papel tradicionalmente feminino: o de adôrno com apelo sexual.

Percebe-se então que o mundo do carnaval reproduz os padrões da sociedade mais ampla e que somente uma participação feminina mais efetiva fora do mundo carnavalesco, ao longo do ano e em todos os níveis e posições sociais, possibilitará uma atuação mais diversificada e intensa da mulher no espaço carnavalesco. 
SIMSON, Olga R. de Mornes von. Mulher e carnaval: mito e realichade.

ABSTRACT: This study points to the analysis of the female presence in the Brazilian Southeastern carnival. The historical perspective surpasses the preoccupations of this study showing differences of opinion between observers. In 1855, limitations toward the participation of women in carnival began and a greater opening has only occured recently in Rio de Janeiro.

KEY-WORDS: Brazilian carnival, female participation, Socio-historical perspective, popular culture, social history. 